\title{
Upaya Peningkatan Penjualan dan Kemandirian Wirausahawan Golok Kecamatan Baros Kabupaten Serang
}

\author{
Ratu Erlina Gentari1 ${ }^{1}$, Lina Marliana Dewi², Ade Nahdiatul Hsanah ${ }^{3 *}$, Suhartini ${ }^{4}$ \\ Universitas Serang Raya \\ Email : 1erlinagentarai@gmail.com, 2linamarlianadewi6@gmail.com, \\ 3*adenahdiatu188@gmail.com, ${ }^{4}$ suhartini@unsera.ac.id \\ *Korespodensi
}

\begin{abstract}
Abstrak
Di Desa Sukamenak sendiri para pengrajin mengelola usaha golok dan pisau nya secara mandiri, dimana kegiatan usaha secara rumahan. Permasalahan utama sampai saat ini belum adanya pembentukan kelompok kerja atau rumah produksi yang dikelola secara professional oleh lembaga atau dinas tertentu untuk mempermudah usaha para pengrajin golok dan pisau ini. Dalam 1 hari pengrajin mampu membuat sampai 15 golok atau pisau biasa, yang nantinya akan dijual ke pasar baros dan pasar rau serang, atau di jual kepada pengepul dengan harga mulai dari Rp.30.000 tergantung ukuran dan bentuk golok. Untuk meningkatkan tingkat perekonomian masyarakat dengan cara memberikan pendidikan dan pelatihan. Kegiatan pendidikan kewirausahaan yang dilakukan tidak hanya memberikan keterampilan wirausaha, akan tetapi menumbuhkan modal sosial masyarakat untuk mewujudkan terbentuknya usahawan baru. Kegiatan yang dilakukan akan difokuskan pada pembentukan satu kelompok masyarakat yang akan diberdayakan. Masyarakat akan diberikan pendidikan dan pelatihan melalui pengelolaan dan pemasaran golok. Metode pelaksanaan yang akan dilakukan terdiri dari lima tahap, yaitu: 1) penyuluhan tentang promosi dan pemasaran golok sebagai peluang usaha. 2) pelatihan pemasaran melalui digital marketing. 3) pelatihan kelayakan ekonomi melalui pemahaman manajemen kewirausahaan yang baik. 4) pelatihan pemasaran produk secara market online maupun offline. Dan 5) Rencana keberlanjutan kegiatan pendidikan dan pelatihan.
\end{abstract}

\begin{abstract}
Abtract
In Sukamenak village, the craftsmen manage their machetes and knives businesses independently, where they operate at home. The main problem to date has not been the formation of working groups or production houses that are professionally managed by certain institutions or offices to facilitate the efforts of these machete and knife craftsmen. In 1 day the craftsmen are able to make up to 15 machetes or ordinary knives, which will later be sold to the baros market and the attacking rau market, or sold to collectors with prices starting from Rp.30,000 depending on the size and shape of the machete. To increase the level of the community's economy by providing education and training. Entrepreneurship education activities carried out not only provide entrepreneurial skills, but also grow social capital to realize the formation of new entrepreneurs. Activities undertaken will be focused on forming one community group that will be empowered. The community will be given education and training through the management and marketing of machetes. The implementation method that will be carried out consists of five stages, namely: 1) counseling about the promotion and marketing of machetes as a business opportunity. 2) marketing training through digital marketing. 3) economic feasibility training through a good understanding of entrepreneurial management. 4) training marketing products online and offline markets. And 5) plans for the continuation of education and training activities.
\end{abstract}

Keyword: Education and Training, Entrepreneurial Manajemen, Digital Marketing, Merketing Product, and Golok Village. 


\section{PENDAHULUAN}

Produk golok dari Desa Sukamenak dan Tejamari Kecamatan Baros Kabupaten Serang Provinsi Banten merupakan salah satu produk senjata multiguna yang banyak di produksi, tidak ada yang tahu pasti di tahun berapa golok dan pisau sukamenak ini pertama kali dibuat dan diproduksi oleh masyarakat. Tapi seluruh masyarakat meyakini bahwa kerajinan golok dan pisau ini merupakan warisan dari leluhur mereka. Semua para pengrajin golok dan pisau di 2 (dua) desa ini merupakan turunan dari orang tua nya, kebanyakan mereka belajar membuat golok dan pisau atau pandai besi ketika mereka masih duduk di Sekolah Dasar hingga saat ini, dan mereka pun menurunkan ilmu nya ke anak-anak nya yang sekarang.

Sekitar 60 rumah dari pekerjaan utama adalah membuat golok adapun permasalahan mereka dalam memproduksi pisau dan golok yang dilakukan dibelakang-belakang rumah dengan kondisi tempat seadanya dan sudah mereka lakukan puluhan tahun yakni tidak mempunyai rumah produksi yang layak, manajemen usaha yang tidak baik dan pemasaran yang seadanya.

Pengrajin memproduksi golok dengan peralatan manual (tanpa mesin khusus) dan menjual hasil produksinya kepada pengepul dengan harga murah. Ditambah lagi Tingkat keahlian rata-rata pengrajin golok memperjelas betapa terbatasnya pengetahuan dan kemampuan dalam penjualan pada era masa kini yang sangatlah menomor satukan kecepatan informasi belum sepenuhnya bisa diikuti dan dimanfaatkan.

Permasalahan yang kompleks tersebut sangatlah mudah kita pahami mengapa pemerintah menerapkan tujuan pemberdayaan UMKM dalam (UU No. 20 Tahun 2008, 2008) tentang usaha mikro kecil dan menengah pasal 5 point a), b) dan c) yakni mewujudkan struktur perekonomian nasional yang seimbang, berkembang, dan berkeadilan, menumbuhkan dan mengembangkan kemampuan Usaha Mikro, Kecil, dan Menengah menjadi usaha yang tangguh dan mandiri, dan meningkatkan peran Usaha Mikro, Kecil, dan Menengah dalam pembangunan daerah, penciptaan lapangan kerja, pemerataan pendapatan, pertumbuhan ekonomi, dan pengentasan rakyat dari kemiskinan. Sehingga undang-undang terebut memperkuat tridharma perguruan tinggi dan memperjelas usaha apa yang harus kita lakukan kepada masyarakat melalui upaya peningkatan penjualan dan kemandirian wirausahawan golok desa sukamenak, sekaligus upaya melestarikan budaya dan kerifan lokal melalui pusaka golok.

Melihat pentingnya upaya pemberdayaan pengrajin untuk meningkatkan kualitas hidup, kemandirian, dan kesejahteraan ekonomi maka diperlukan rangkaian kegiatan yang melibatkan pemerintah daerah dan termasuk pendampingan institusi perguruan tinggi secara berkelanjutan (Krisnanik, n.d.). Kegiatan tersebut dilakukan melalui 1) penyuluhan tentang promosi dan pemasaran golok sebagai peluang usaha. 2) pelatihan pemasaran melalui digital marketing. 3) pelatihan kelayakan ekonomi melalui pemahaman manajemen kewirausahaan yang baik. 4) pelatihan pemasaran produk secara market online maupun offline. Dan 5) Rencana keberlanjutan kegiatan pendidikan dan pelatihan.

Dalam kajian teori mengenai promosi dan pemasaran umumnya kegiatan promosi tidak hanya berfungsi sebagai alat komunikasi antara pengrajin dan pembeli, melainkan berfungsi untuk mempengaruhi proses trasaksi pembelian yang sesuai kebutuhan (Supranto, 2018). Maka perlu deskripsi usaha yang jelas untuk menentukan hasil produk yang diharapkan. Apakah usaha akan lebih memenuhi pasar golok sesuai fungsi pemakaian ataukah hanya sekedar nilai estetika atau pasar golok cinderamata.

$17 \mid \mathrm{K}$ a ib o n A b hin a y 
Digital marketing merupakan hasil ketersinggungan gagapnya masyarakat golok dalam mengikuti trend transformasi informasi. (Widiawati, 2019) Modalnya hanya kreatifitas dan keberanian. Siapapun bisa membuka gerai online melalui platform tersulit berbasis website sampai yang termurah dan gampang yaitu media sosial, tanpa harus membuka toko fisik terlebih dulu. Produk bisa berupa makanan, minuman, aplikasi, jasa, dan sebagainya. Mengikuti dan memanfaatkan perkembangan TIK maka akan mempermudah promosi dan pemasaran.

Menurut buku manajemen kewirausahaan (Kurnia Dewi, 6:2020) bukan hanya memaklumi peran penting teknologi dan ideologi usaha berupa klasterisasi usaha saja yang perlu dikenalkan dan diterapkan tapi juga keberanian usaha secara mandiri dengan menerapkan manajemen kewirausahaan agar terciptanya peluang usaha baru dengan mengerahkan sumber daya dan upaya baru. Dengan manajemen kewirausahaan akan terlihat kemampuan sesorang dalam mengenali produknya, sanggup menyusun operasi dan peluang-peluang yang ada, akan ada produkproduk baru yang diciptakan dan dipasarkan, serta mampu mengatur permodalan dan mengawari resiko usaha yang dihadapi.

Tiga point kegiatan di atas merupakan kata kunci utama yang akan selalu bersiklusisasi, maka tidak heran keberlanjutan harus dijadikan pendukung perkembangan usaha pengrajin. Diiringi jenjang pelatihan pemasaran produk secara online maupun offline mulai dari pelatihan aplikasi dan platform termudah dan murah sampai yang berbasis website.

Melalui seluruh kegiatan yang telah tersusun, dan memperoleh dukungan dari perangkat desa yang ada serta materi-materi apik diharapkan mampu meningkatkan nilai jual produk golok dan membentuk kemandirian baru.

\section{METODE PELAKSANAAN}

Metode yang dilakukan pada pengabdian kepada masyarakat ini adalah melakukan analisa lapangan, sosialisasi kegiatan, pendidikan dan pelatihan. Adapun penjelasan kegiatan tersebut adalah sebagai berikut:

1) Analisa Lapangan.

Pada tahap ini kami mengadalan analisis lapangan melaui observasi dan survei lapangan yang kami adakan. Dari hasil observasi lapangan ini kami menemukan permasalahan kontrasnya kemakmuran pengrajin golok dengan para tengkulaknya. Dari hasil analisa lapangan ini pula kami memutuskan untuk berkoordinasi dengan perangkat desa setempat dan tokoh masyarakat untuk meminta ijin dalam membuka kegiatan sosialisasi, pendidikan dan pelatihan dalam upaya peningkatan taraf ekonomi pengarajin.

2) Sosialisasi Kegiatan.

Sejalannya persetujuan dari perangkat desa dan tokoh masyarakat, maka selanjutnya kami dan dibantu mahasiswa peserta KKM 2019 melakukan sosialisasi kegiatan yang tersusun dengan mengedarkan surat edaran sosialisasi kelompok KKM yang sudah disetuji dosen pembimbing dan kepala desa sekaligus silaturahmi door to door kepada pengrajin dan menjelaskan maksud, tujuan da pentingnya kegiatan tersebut.

3) Pelatihan.

Ada 2 (dua) fokus pelatihan yang dirancang dan dilaksanakan, yang pertama adalah pelatihan pembuatan digital marketing menggunakan media aplikasi facebook, instragram, whatsapp dan line. Dan kedua pelatihan konten pemasaran pada kemasan produk manfaat promotion link pada instagram dan facebook adv. Serta dilengkapi materi manajemen kewirausahaan.

Proses pelaksanaan kegiatan terangkum pada bagan dibawah ini: 


\section{Tabel 1. Proses Pelaksanaan dan Tujuan}

\begin{tabular}{|c|c|c|}
\hline No & Kegiatan & Tujuan \\
\hline 1. & Analisa Lapangan & \\
\hline a. & $\begin{array}{ll}\text { Menyebarkan } & \\
\text { Kuesioner } & \\
\text { Demografi } & \text { Dan } \\
\text { Sensus Sosial } & \text { Dan } \\
\text { Ekonomi } & \\
\text { Masyarakat } & \text { Desa } \\
\text { Oleh 16 Mahasiswa } \\
\text { Peserta KKM } & 2019 \\
\text { UNSERA } & \\
\end{array}$ & $\begin{array}{l}\text { Untuk } \\
\text { mengetahui } \\
\text { gambaran jelas } \\
\text { dan real count } \\
\text { status sosial dan } \\
\text { ekonomi seluruh } \\
\text { penduduk }\end{array}$ \\
\hline b. & $\begin{array}{l}\text { Koordinasi } \begin{array}{r}\text { Hasil } \\
\text { dengan }\end{array} \\
\text { Dorvey Pembimbing } \\
\text { Lapangan, 1 Orang } \\
\text { Dosen FEB dan } 2 \\
\text { Orang r Dosen } \\
\text { Vokasi UNSERA } \\
\text { beserta Perangkat } \\
\text { Desa dan } 6 \text { Orang } \\
\text { Tokoh Masyarakat. }\end{array}$ & $\begin{array}{l}\text { Untuk } \\
\text { memperoleh } \\
\text { mufakat kegiatan } \\
\text { selanjutnya dari } \\
\text { permasalahan } \\
\text { yang diterima. }\end{array}$ \\
\hline \multirow[t]{2}{*}{2.} & Sosialisasi & \\
\hline & $\begin{array}{l}\text { Menyebarkan Surat } \\
\text { Edaran dan } \\
\text { Undangan }\end{array}$ & $\begin{array}{l}\text { Untuk } \\
\text { menyebarkn } \\
\text { informasi terkait } \\
\text { kegiatan yang } \\
\text { telah disusun dan } \\
\text { disepakati oleh } \\
\text { kepala } \\
\text { kepada desa } \\
\text { masyarakat secara } \\
\text { tertulis melalui } \\
\text { surat edaran dan } \\
\text { undangan dan } \\
\text { dilakukan door to } \\
\text { door. }\end{array}$ \\
\hline
\end{tabular}

\begin{tabular}{|c|c|c|}
\hline 3. & Pela & \\
\hline a. & $\begin{array}{l}\text { Pelatihan } \\
\text { Pembuatan Digital } \\
\text { Marketing } \\
\text { Menggunakan } \\
\text { Media Aplikasi } \\
\text { Facebook, } \\
\text { Instragram, } \\
\text { Whatsapp Dan Line }\end{array}$ & $\begin{array}{l}\text { Praktek langsung } \\
60 \quad \text { peserta } \\
\text { pembuatan akun } \\
\text { pribadi pengrajin } \\
\text { dalam memasaran } \\
\text { produk }\end{array}$ \\
\hline b. & $\begin{array}{lr}\text { Pelatihan } & \text { Konten } \\
\text { Pemasaran } & \text { Pada } \\
\text { Kemasan } & \text { Produk } \\
\text { Manfaat Promotion } \\
\text { Link } & \text { Pada } \\
\text { Instagram } & \text { Dan } \\
\text { Facebook Adv. }\end{array}$ & $\begin{array}{lr}\text { Melalui } & \text { akun } \\
\text { yang sudah } \\
\text { dibuat langsung } \\
\text { dipraktekan } \\
\text { memasang } & \text { konten } \\
\text { produk } & \text { sesuai } \\
\text { kebutuhan } & \text { golok } \\
\text { sebagai } & \text { golok }\end{array}$ \\
\hline
\end{tabular}

(c) Ratu Erlina Gentari, et al

\begin{tabular}{|c|c|}
\hline & $\begin{array}{l}\text { yang dipakai } \\
\text { fungsi aslinya dan } \\
\text { golok sebagai } \\
\text { souvenir) dan } \\
\text { langsung } \\
\text { mengunakan } \\
\text { fasilitas promosi } \\
\text { link instagram ke } \\
\text { beberapa apps } \\
\text { dan facebook adv } \\
\text { yang mampu link } \\
\text { ke instagram dll. }\end{array}$ \\
\hline $\begin{array}{ll}\text { c. Pemberian Materi } \\
\text { Manajemen } \\
\text { Kewirausahaan. }\end{array}$ & $\begin{array}{l}\text { Para pendamping } \\
\text { pengrajin dapat } \\
\text { mempelajari } \\
\text { apaitu } \\
\text { kewirausahaan } \\
\text { dan bagaimana } \\
\text { proses baik } \\
\text { berwirausaha } \\
\text { yang sehingga bisnis } \\
\text { budaya lokal ini } \\
\text { dapat terus } \\
\text { memiliki inovasi } \\
\text { dan dilestarikan. }\end{array}$ \\
\hline
\end{tabular}

Berikut adalah dokumentasi yang berhasil diabadikan dalam proses pelaksanaan.

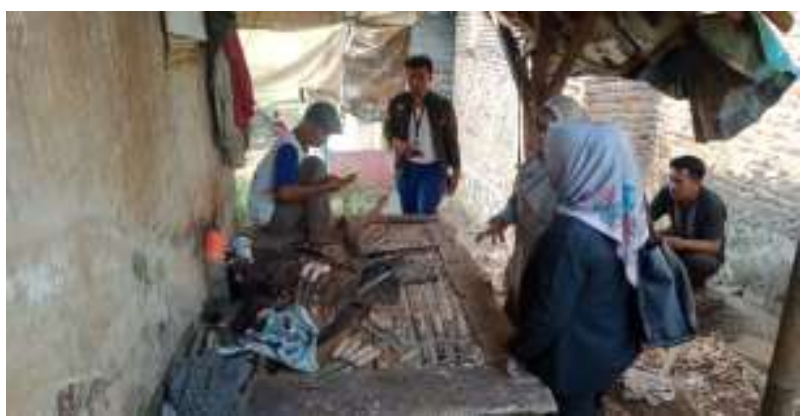

Gambar 1. Proses Sosialisasi Kegiatan Dosen Pembimbing, Dosen FEB, Dosen Vokasi Bersama Anggota KKM Unsera 2019 kelompok Baros

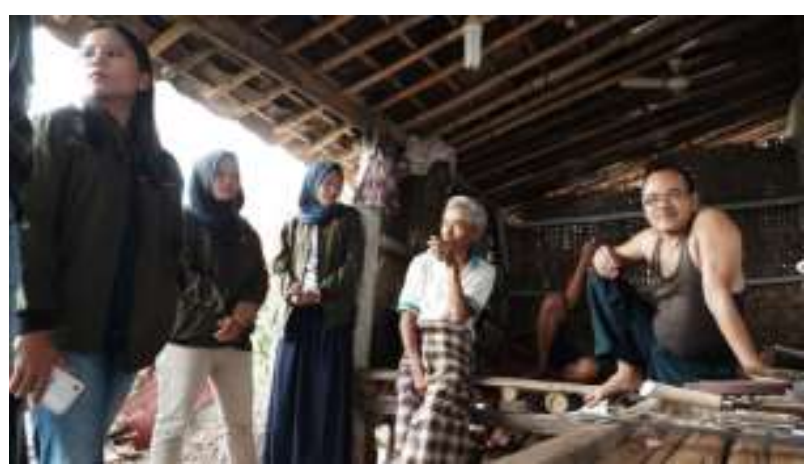

$19 \mid \mathrm{K}$ a ib on A b h in a y 


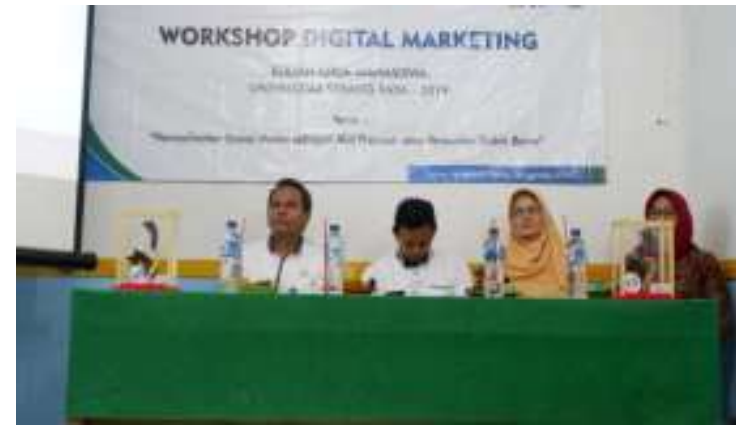

Gambar 3. Pembukaan Kegiatan Pelatihan Oleh Dosen Pembimbing, Dosen FEB, Dosen Vokasi Bersama Kepala Desa Sukamenak dan Tokoh Masyarakat.

\section{HASIL DAN PEMBAHASAN}

Pelaksanaan pengabdian kepada masyarakat bertujuan untuk memberikan pendidikan dan pelatihan tentang memasarkan produk yang telah di buat, menumbuhkan kemandirian pengrajin sebagai pelaku usaha tulen, dan menumbuhkan minat berwirausaha bagi generasi muda. Sehingga adanya peningkatan penjualan yang akan berkorelasi dengan peningkatan kemakmuran pengrajin.

\section{Tabel 2. Hasil Capaian}

\begin{tabular}{|c|c|c|c|}
\hline No & Kegiatan & Tujuan & Capaian \\
\hline 1. & \multicolumn{3}{|c|}{ Analisa Lapangan } \\
\hline a. & $\begin{array}{l}\text { Menyebar } \\
\text { kan } \\
\text { Kuesioner } \\
\text { Demograf } \\
\text { i Dan } \\
\text { Sensus } \\
\text { Sosial Dan } \\
\text { Ekonomi } \\
\text { Masyarak } \\
\text { at Desa } \\
\text { Oleh } 16 \\
\text { Mahasisw } \\
\text { a Peserta } \\
\text { KKM 2019 } \\
\text { UNSERA }\end{array}$ & $\begin{array}{l}\text { Untuk } \\
\text { mengetah } \\
\text { ui } \\
\text { gambaran } \\
\text { jelas dan } \\
\text { real count } \\
\text { status } \\
\text { sosial dan } \\
\text { ekonomi } \\
\text { seluruh } \\
\text { penduduk }\end{array}$ & $\begin{array}{l}\text { - Terdapat } \\
\text { klasterisasi } \\
\text { tingkat } \\
\text { kemakmuran } \\
\text { masyarakat dari } \\
\text { dilihat dan } \\
\text { penghasilan } \\
\text { utama takang } \\
\text { tambahan antara } \\
\text { lain, sebagai } \\
\text { petani, tukang } \\
\text { ojek pangkalan, } \\
\text { pedagang } \\
\text { kelontong, } \\
\text { kredit barang } \\
\text { kebutuhan } \\
\text { rumah tangga, } \\
\text { peternak, } \\
\text { pemilik tambak } \\
\text { ikan, pembuat } \\
\text { tempe, pembuat } \\
\text { tape dan }\end{array}$ \\
\hline
\end{tabular}

\begin{tabular}{|c|c|c|c|}
\hline & & & $\begin{array}{l}\text { pengrajin golok; } \\
\text { dan } \\
\text { - Rangkuman } \\
\text { penjelasan } \\
\text { mengenai } \\
\text { masalah yang } \\
\text { menimbulkan } \\
\text { kesenjangan di } \\
\text { desa. }\end{array}$ \\
\hline b. & $\begin{array}{l}\text { Koordinas } \\
\text { i Hasil } \\
\text { Survey } \\
\text { dengan } \\
\text { Dosen } \\
\text { Pembimbi } \\
\text { ng } \\
\text { Lapangan, } \\
1 \text { Orang } \\
\text { Dosen } \\
\text { FEB dan } 2 \\
\text { Orang } \\
\text { Dosen } \\
\text { Vokasi } \\
\text { UNSERA } \\
\text { beserta } \\
\text { Perangkat } \\
\text { Desa dan } \\
6 \\
\text { Tokoh Orang } \\
\text { Masyarak } \\
\text { at. }\end{array}$ & $\begin{array}{l}\text { Untuk } \\
\text { memperol } \\
\text { eh } \\
\text { mufakat } \\
\text { kegiatan } \\
\text { selanjutny } \\
\text { a dari } \\
\text { permasala } \\
\text { han yang } \\
\text { diterima. }\end{array}$ & 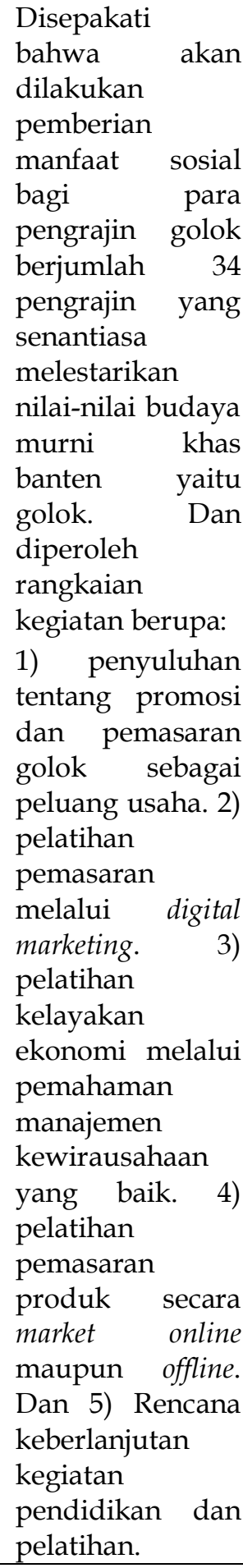 \\
\hline \multirow[t]{2}{*}{2.} & Sosialisasi & & \\
\hline & $\begin{array}{l}\text { Menyebar } \\
\text { kan Surat }\end{array}$ & $\begin{array}{l}\text { Untuk } \\
\text { menyebar }\end{array}$ & $\begin{array}{l}\text { Tersampaikanny } \\
\text { a maksud dan }\end{array}$ \\
\hline
\end{tabular}

$20 \mid \mathrm{K}$ a ibon A b hin a y 


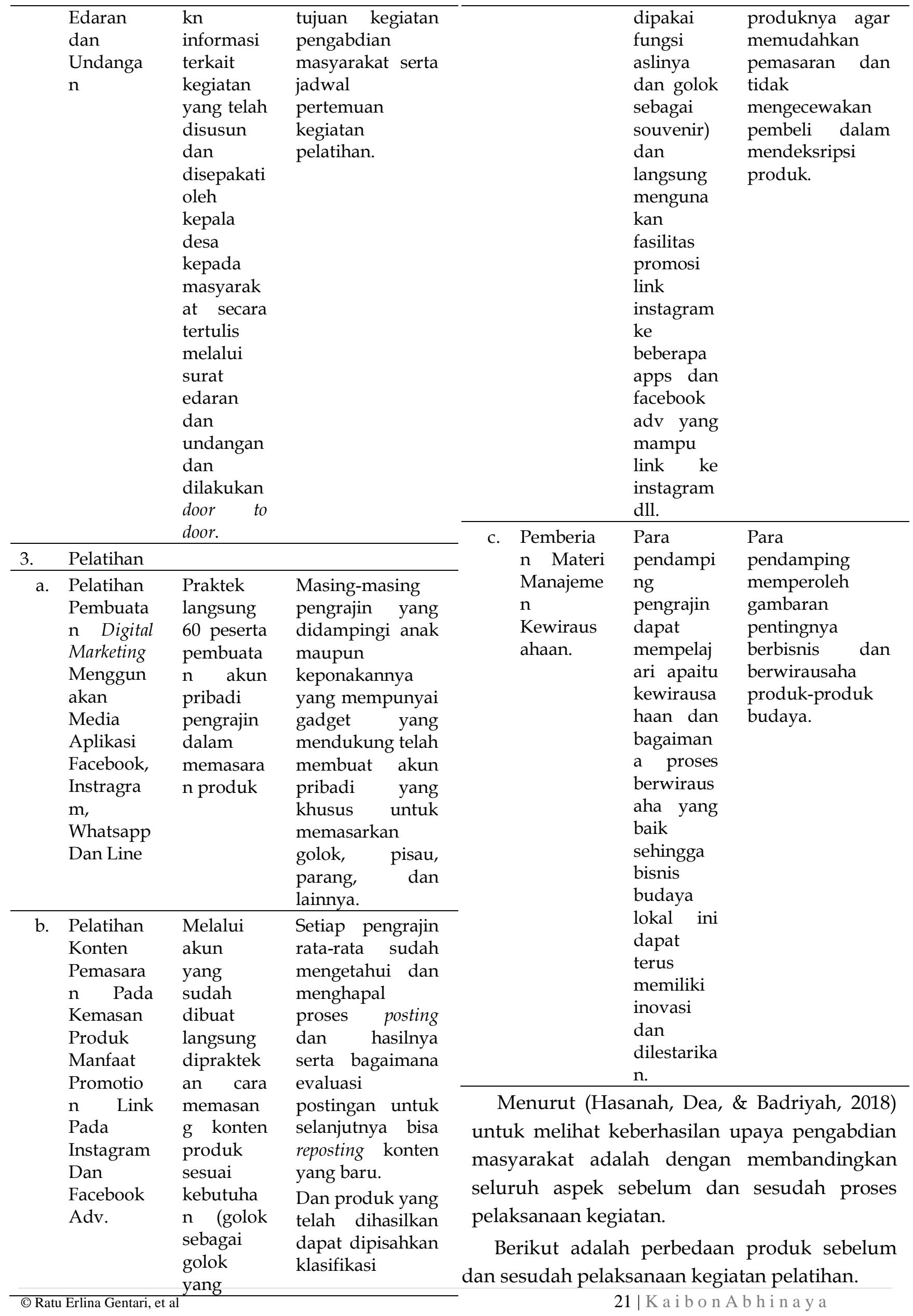




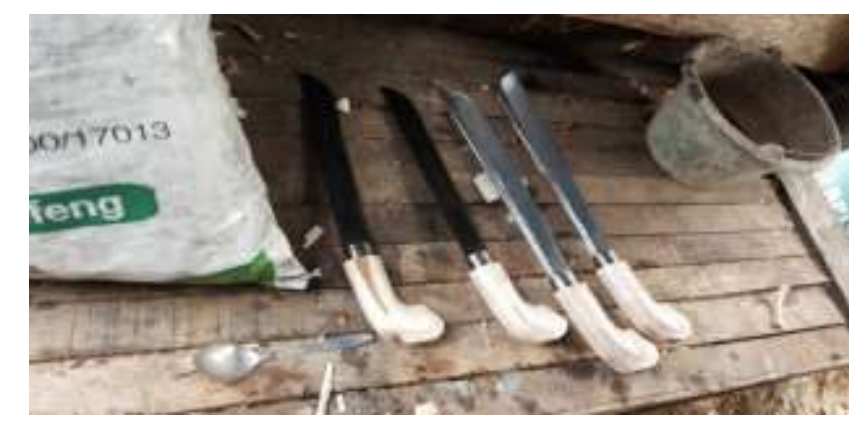

Gambar 4. Golok sebelum adanya pelatihan dari kegiatan pengabdian masyarakat

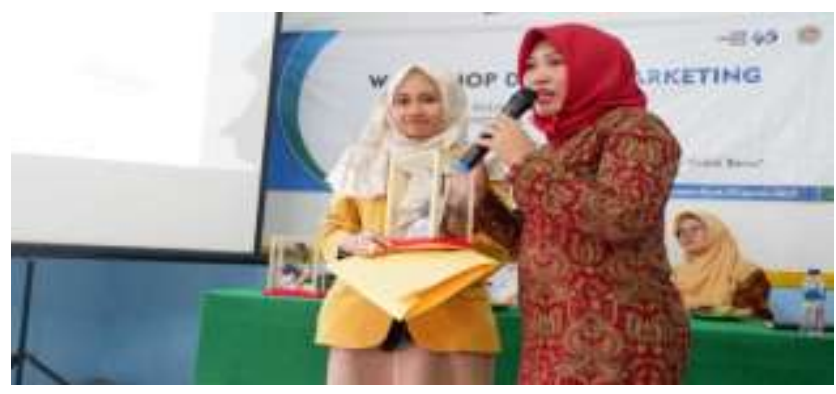

Gambar 5. Golok yang dirancang sebagai souvenir

\section{Ucapan Terima Kasih}

Terimakasih kepada pengrajin golokdan perangkat pemerintah desa sukamenak dan desa tejamari atas semangat, tenaga dan fikiran dalam mengikuti pelaksanaan kegiatan pengabdian masyarakat. Terimakasih kepada kelompok KKM UNSERA 2019, LPPM Universitas Serang Raya atas dukungan sehingga kegiatan pengabdian masyarakat ini dapat memberikan manfaat dan keberkahan bagi perkembangan dan pelestarian golok banten.

\section{KESIMPULAN DAN SARAN}

\section{Kesimpulan}

Dari hasil pelaksanaan kegiatan kita memperoleh rangkuman capaian sebagai berikut:

1) Pengrajin memiliki akun media sosial pribadi yang aktif dan produktif khusus untuk memasarkan golok, pisau, parang, dan lainnya;

2) Pengrajin memiliki kemampuan dan pengetahuan memasarkan produknya kepada masyarakat global melalui media elektronik dan kemasan sesuai kebutuhan;

3) Kini tidak ada lagi golok yang dijual kepada perantara (tengkulak); dan

4) Golok yang diproduksi memiliki ragam kegunaan. Bisa dipakai sebagaimana fungsinya juga bisa dipergunakan sebagai oleh-oleh (souvenir).

\section{Saran}

Dalam perjalanan proses kegiatan, ada banyak hambatan dan kelemahan yang dapat mengancam batalnya acara pelatihan yakni kurangnya komunikasi dengan pengrajin dengan perangkat desa. Maka dengan ini kami sangat mengharapkan dan menghimbau untuk bersama-sama mewujudkan amanah negara yang tertuang dalam UU No. 20 Tahun 2008 Tentang Usaha Mikro Kecil dan Menengah.

\section{DAFTAR REFERENSI}

Kurniati Dewi, Manajemen Kewirausahaan, Penerbit Deepublish 2020

Hasanah, A. N., Dea, R., \& Badriyah, M. (2018).

Proceeding of Community Development

Pengembangan Usaha Makanan Melalui

Teknologi Kemasan Produk Di Kecamatan

Kramatwatu Kabupaten Serang Abstrak, 2, 241-249.

Krisnanik, E. (n.d.). Pendahuluan Metode

Pengabdian. 2019, 233-239.

Supranto. (2018). REPOSITORY UNPAS SUPRANTO 2018.pdf.

UU No. 20 Tahun 2008. (2008). No Title.

Widiawati, K. (2019). Penerapan Digital Marketing Sebagai Pendukung Sociopreneur Teh Bunga Telang ( Butterfly Pea Tea ), 7(2), 215-224. 
